\title{
Telling the Future: Reflections on the Status of Divination in Ancient Near Eastern Politics
}

\section{Stefan M. Maul}

When there were political decisions to be made in the ancient Near East, ${ }^{1}$ cuneiform sources from two millennia show us that kings and their counselors did not rely exclusively on their own professional expertise. They held off, rather, on putting a plan into action until its feasibility had been examined and confirmed by an independent "expert advisory board." The authority attributed to this examination can hardly be overestimated. This is proven by the mere fact that rulers submitted to it without dissent, in spite of the risk that their plan might be judged untenable. An assessment by these experts, on the other hand, had the benefit of guaranteeing reliable predictions as to the success of a given undertaking. For the experts had at their fingertips the knowledge and procedures to be able to look back, in a manner of speaking, from the vantage point of the future and see the consequences of an intended action, and thereby identify those plans and purposes that would lead to undesired outcomes. Naturally the prospect of such knowledge was of inestimable worth to political decision makers, because to those who sought such advice and received a positive verdict, it delivered the certainty of having chosen a path that was oriented toward the future and assured of success.

As insightful and rational as it may sound to test the viability of a given scheme before putting it into practice, the means by which such evaluations were made in the ancient Near East seem just as wrongheaded and downright absurd-at least from the perspective of our current worldview. Namely, the future prospects of a plan were regularly determined in royal palaces over the course of centuries from the color and shape of the liver of a sheep that had been slaughtered for this very purpose (Jeyes, 1993; Leiderer, 1990; Meyer, 1987; Starr, 1983, 1990).

\footnotetext{
${ }^{1}$ For a general introduction into the history and culture of the ancient Near East see Oppenheim (1996) and Sasson (1995).

S.M. Maul (ه)

Department of Languages and Cultures of the Near East - Assyriology, Heidelberg

University, Hauptstraße 126, 69117 Heidelberg, Germany

e-mail: stefan.maul@ori.uni-heidelberg.de
} 
This procedure had developed into a proper "science" that correlated the appearance of a sheep's liver with future events. By the application of a system of rules, which in themselves seem quite systematic and logical, certain features on the surface of the liver were interpreted as favorable or unfavorable signs (Maul, 2003, pp. 69-82, 2013).

The experts checked systematically — going counter-clockwise-for the presence and undamaged condition of about a dozen anatomically constitutive elements on the surface of the liver (Koch-Westenholz, 2000, 2005), inspecting not only the gallbladder, but also looking for furrow-like markings and notches, distinctively textured surfaces, conspicuous protrusions, and the remains of ligaments that had been attached to the liver (Fig. 5.1).

The undamaged condition of the individual parts of the liver was seen as favorable. Furthermore, the location of certain features that could occur anywhere in the twelve regions of the liver played a fundamental role in the evaluation process. Among these were protruding lymph nodes, membranes, bubbles, warts, and holes in the liver tissue (Leiderer, 1990). The latter were open, occasionally calcified cavities in the surface of the liver caused by liver flukes, bladder worms, and other common parasites. Some of these characteristics, such as holes, were regarded as harbingers of evil. Others, however, such as slight bubbles caused by bladder worms, were positively construed (Fig. 5.2).

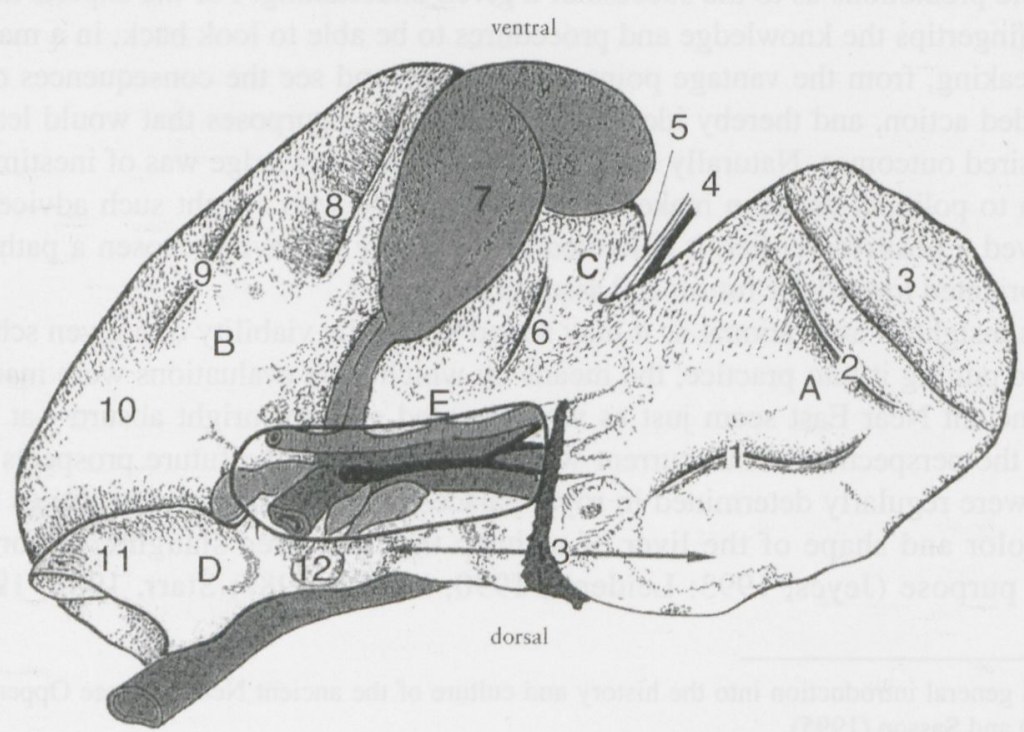

Fig.5.1 Schematic drawing of a sheep's liver. The numbers $1-13$ indicate the regions of the liver being checked, including the gallbladder $(7)$ and several furrow like markings $(1,2,6,8,9)$ (From Anatomie der Schafsleber im babylonischen Leberorakel: Eine makroskopisch-analytische Studie (p. 158, Fig. 2), by R. Leiderer, 1990, Munich: Zuckschwerdt. Copyright by Zuckschwerdt. Reprinted with permission) 


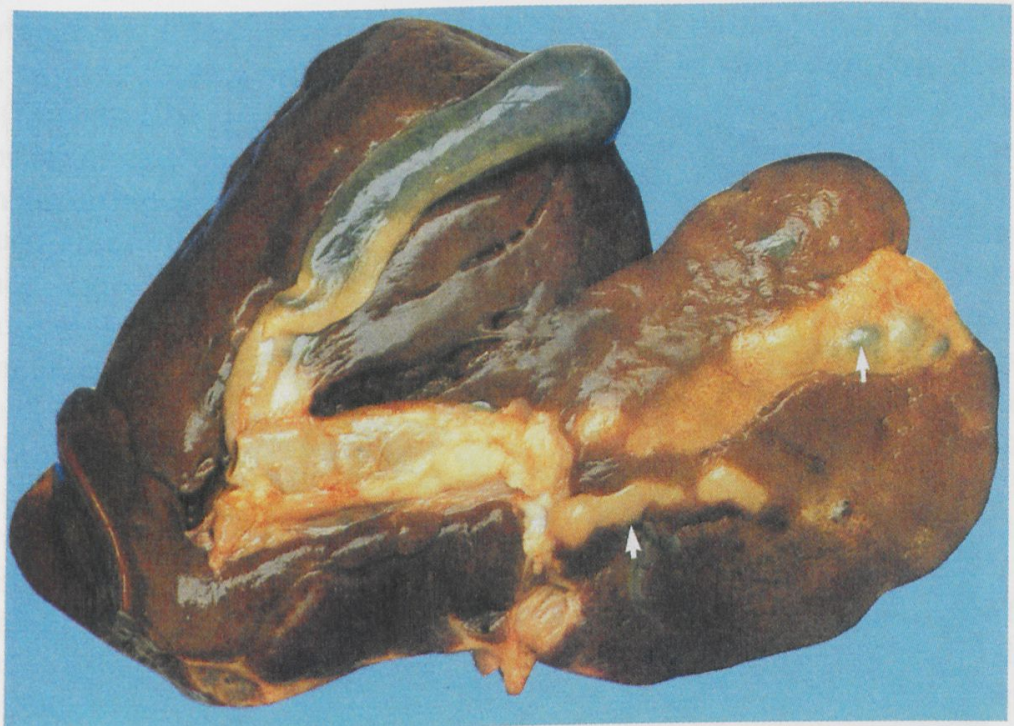

Fig.5.2 A fresh sheep's liver infested by parasites. The arrows indicate bubbles caused by bladder worms. (From Anatomie der Schafsleber im babylonischen Leberorakel: Eine makroskopischanalytische Studie (p. 161, Fig. 7), by R. Leiderer, 1990, Munich: Zuckschwerdt. Copyright by Zuckschwerdt. Reprinted with permission)

Although no two healthy livers are ever exactly alike, pathological phenomena ranging from inflammation to parasite infestation and necrosis lead to shockingly different findings. To facilitate the evaluation of certain characteristics as positive or negative, the inspection of a liver was approached with downright mathematical precision. A grid pattern was projected over each of the twelve constitutive parts of the liver, for instance over the gallbladder (Meyer, 1987 passim). The middle area of this grid was assigned to a fundamentally benign power of fate, the area to the right to an endorsement of the plan being evaluated, and the area to the left to the powers that opposed the plan. A characteristic construed as positive observed in the middle section was a positive finding, because fate was indeed revealing itself as benign. If the same sign appeared in the section to the right, this was also evaluated as a positive sign. But a sign of this type in the left section, which represented the powers opposing the plan, had the effect of strengthening those powers and thus became an unfavorable sign. A characteristic construed as negative, on the other hand, operated in the middle and right sections according to the mathematical formula $+x-=-$ (a positive times a negative equals a negative). In the left section of the grid, however, a weakening of the opposing powers amounted to strength, and hence a characteristic considered to be negative, if found in this section, was evaluated as a favorable sign. Admittedly, this procedure was in practice much more complicated. Not only did the system of analysis divide the gallbladder still further into subdivisions, which in turn were evaluated, but the entire liver was conceived of as a network of positively and negatively charged sections (Nougayrol, 1968). An 


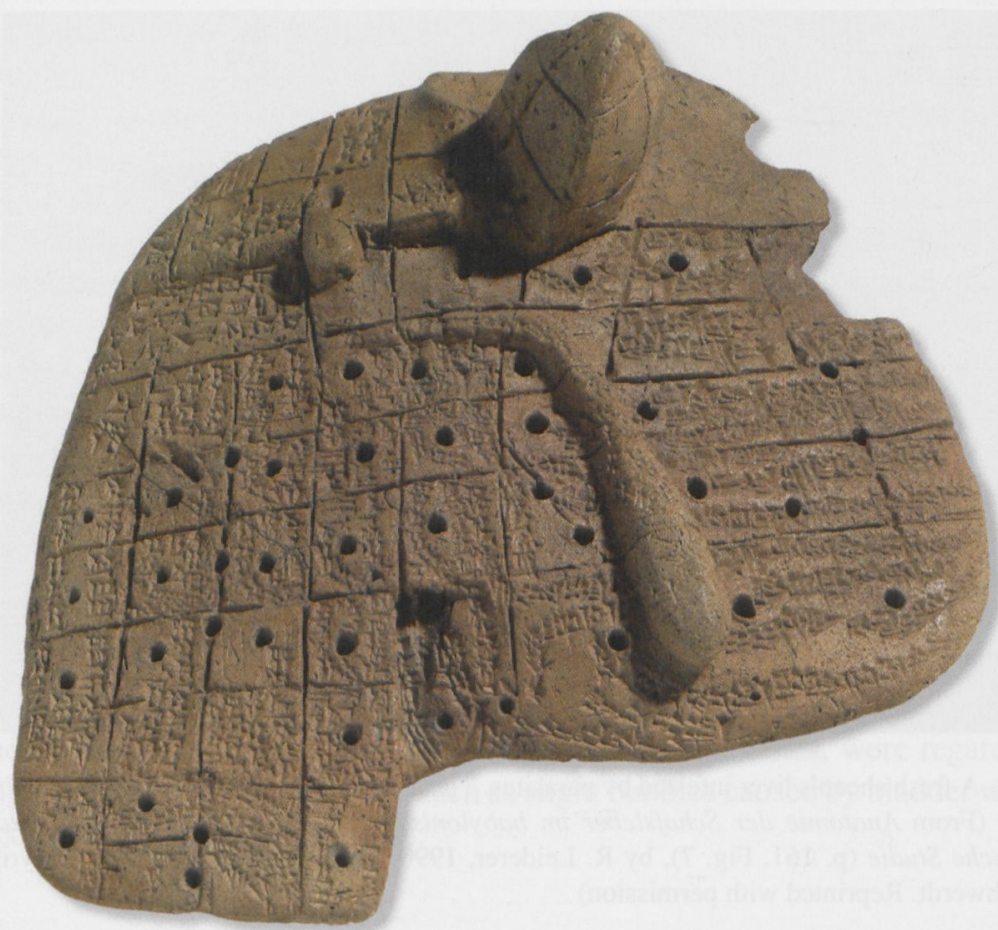

Fig.5.3 An inscribed sheep's liver model from the Old Babylonian period (seventeenth century B.C.) (From British Museum Images, inventory number 00032437001. Copyright: The Trustees of the British Museum. Reprinted with permission)

Old Babylonian liver model from the seventeenth century B.C., made for teaching purposes, documented this layout for the ancient student using the example of a negatively construed cavity in the organ surface, as is seen in the photograph (Fig. 5.3). The respective meaning of the hole in each individual parcel is noted in cuneiform (Nougayrol, 1941, pp. 77-79).

Without going into further detail, this much can be said: professional haruspices claimed the ability, at least in the first millennium B.C., to calculate the validity of their predictions with a mathematical formula, in which certain numerical values must have been assigned on the basis of certain liver characteristics (KochWestenholz, 2005, pp. 63-66, 459-479).

The verdict on a given plan's prospects for success resulted from the simple addition of positive and negative signs. If there were more positive signs, the project was judged as desirable and cleared for implementation. If the negative signs were in the majority, then the evaluation was negative.

Decisions were made in this way in ancient Near Eastern courts about personnel issues, building projects, and even on the question of whether and when to go to war (Starr, 1983). Furthermore, in the eighteenth century B.C. it was routine in Old 
Babylonian Mari $^{2}$ to inquire each month by means of extispicy ${ }^{3}$ into the security of king, city and country, with the goal of warding off heretofore unrecognized dangers (Durand, 1988, pp. 57-58). The cause of the potential danger was established by means of carefully crafted questions, formulated in conjunction with the liver examination process (Lambert, 2007).

Such an examination procedure stands in opposition to modern conventional science, above all because it is blatantly unconcerned with the background and purpose of the undertaking in question. Nonetheless, over the course of more than two millennia, the Mesopotamians—and their neighbors as well—saw the mastery of such divinatory procedures as a decisive reason for the lasting cultural and geopolitical success of Babylonia and Assyria. Indeed, extispicy's reputation for effectiveness was so great that it outlived ancient Near Eastern civilization, being regarded as an indispensable means of political decision making in Greece, Etruria, and Rome (Collins, 2008; Pfiffig, 1975; Thulin, 1968).

The certainty that the process outlined here could afford a glimpse into the future rested on the belief, also current today, that the observable world contains traces of an unfolding future, which need to be recognized and interpreted. In the ancient Near East, every form of movement and change in all realms of experience, on earth as well as in the heavens, was understood as part of the vastly complex process of the world's development through time. All perceptible phenomena, however mundane they might be individually, were considered interrelated, for they are all part of the movement of the whole toward the future (Maul, 2003). Therefore, viewed individually or, even better, in conjunction, they allowed the ancient Near Eastern observer to project future events. The movement of the whole toward the future-as observed in the growth and development in nature, the alternation of day and night, the course of the year, and the progress of the heavens - was orderly and harmonious, and perceived as such. Every anomaly in nature, on the other hand, was thought to have been provoked by human beings. More precisely, it was considered to be a reaction to human deeds and probably desires as well. Deviations from regularity, such as abnormalities among plants and animals (Freedman, 1998; Moren, 1978), in the night sky (Rochberg-Halton, 2004), or on the surface of a sheep's liver (KochWestenholz, 2000, 2005), were perceived as messages to mankind that required their recipients to take stock of their situation and put things to rights, so that disorder could be eliminated and harmony restored (Maul, 1994).

The current experience with human-induced climate change may afford a perspective that gives an inkling of the rationale behind such notions. Be that as it may, the fundamental conviction that the entire cosmos is interactively centered on human beings subsided in the ancient oriental world in the seemingly compliant idea of gods mercifully using portent to guide humans down the right path, even though they ultimately had to bow to divine will anyway. Yet this conviction also fired an unquenchable spirit of exploration aimed at disclosing the inherent laws of

\footnotetext{
${ }^{2}$ Mari (modern Tell Hariri, Syria) was an ancient Sumerian and Amorite city.

${ }^{3}$ Extispicy is the inspection of the entrails of sacrified animals, especially the livers of sheep and poultry.
} 
the world's semiotic character and recognizing them in vastly different systems. Along with extispicy, the "science" of interpreting celestial omens had advanced far enough by the early first millennium B.C. that Babylonian and Assyrian kings regularly used it to make political decisions (Brown, 2000; Hunger, 1992; KochWestenholz, 1995; Maul, 2003, pp. 51-57; Rochberg-Halton, 2004). For the night sky - unlike extispicy - yielded unsolicited signs and offered an unceasing flow of information about the future. In the Neo-Assyrian period all of Mesopotamia was thus crisscrossed with a network of observation posts, which sent reports independently of one another to the king's palace in Nineveh, where these were compared and evaluated (Hunger, 1992; Oppenheim, 1969). Unlike the liver, however, the heavens - as the reflected image of the whole earth-were consulted for information not about the individual, but about matters of a national and even global nature. As such they even yielded predictions on the destiny of neighboring hostile lands. For this reason, astrology in the ancient Near East was of the greatest political interest. For, through the evaluation of the apparently irregular movements of celestial bodies, it seemed to offer the possibility of discerning opportunities as well as threats, of both avoiding disaster and taking advantage of particularly auspicious moments.

Numerous scholarly writings from the first millennium B.C. show that Mesopotamian diviners wanted to bring together insights from the two most important fields of divination, extispicy and astrology (Heeßel, 2008; Koch-Westenholz, 2005, pp. 30-31). Their reflections, which are still only partially understood, did not merely result in the liver's being conceived of as an emanation of the heavens, in a certain sense, and divided up into exactly twelve segments, like the zodiac. Mesopotamian scribes also thought it was possible to correlate the signs of the liver with equivalent astral signs (Reiner, 1995, p. 78; von Weiher, 1993, p. 159) and thus to trace the laws governing the dynamics of world events in various media.

Toward this end they collected signs not just for the purpose of telling the future. They also examined the present-that is, yesterday's future-in order to check for corresponding signs in the past that they might have overlooked. The astronomical diaries (Hunger \& Sachs, 1988-2006) represent an ambitious attempt carried out over the course of centuries (with gaps from the seventh to first centuries B.C.) to shed more light on the interaction of causal events. In the form of yearly reports, the diaries record not only astral signs and the weather, but also water levels, price fluctuations, and historical events. The goal was to identify the laws that governed the world, in order to utilize them in the realm of politics. First millennium Babylonians thus developed mathematical astronomy, a branch of Babylonian learning that has survived until today (Hunger \& Pingree, 1999; Neugebauer, 1975).

These various ancient Near Eastern divinatory procedures were intended to ensure that decisions and actions by those responsible for the common good remained in harmony with the all-encompassing flow of world events, which humans ultimately cannot resist. Mesopotamia's political and cultural dominance, a centuries-old tradition that had never been seriously questioned, and the embeddedness of divination in a type of scholarly system-reinforced by the considerable expenditure required by divinatory procedures - made the success of the Mesopotamian 
"science of telling the future" incontrovertible in the eyes of Mesopotamians and the surrounding peoples. They were convinced that divination guaranteed a high measure of stability and prosperity, and prevented major errors of judgment, thus offering a considerable and lasting advantage over others.

As a matter of course, Assyrian and Babylonian kings attempted to monopolize the knowledge and techniques of looking into the future and to bind its best practitioners to their courts (Pongratz-Leisten, 1999). This knowledge was so highly valued, that in times of war, tablets with divinatory content were plundered by explicit royal command (Lambert, 1957/1958, p. 44; see Parpola, 1983). The knowledge that dynasties of diviners had developed and transmitted from father to son was collected, systematized, and compiled in extensive text editions in the late second and early first millennium B.C.. The impetus for this was probably the ever increasing royal demand for divinatory counsel, which kept pace with the growing complexity of Mesopotamian ruling institutions. These new editions then formed the royally authorized and authoritative lexicon of classified divinatory expertise, which specialists in the service of the king were obliged to consult. Divinatory expertise was henceforth almost solely under royal control. Diviners in the king's service were involved in highly confidential matters and were required to take an oath of silence regarding any politically charged information they might have access to through their activities (Durand, 1988, pp. 13-15; see Parpola, p. 7) The profession of divination was so well organized in the Neo-Assyrian empire of the first millennium B.C. that reports on ominous events, mainly celestial but also terrestrial, came in regularly from the entire domain (Koch-Westenholz, 1995, pp. 180-185; Oppenheim, 1969). These mutually complimentary reports were directed to a commission that one could somewhat anachronistically call "the Ministry for the Future." Here they were harmonized, checked for internal consistency, and evaluated before any resulting political measures were taken.

That this was an effective form of political decision-making is proven by Mesopotamia's 3,000-year-long political and cultural domination of the entire Near East. And yet, from a modern perspective, the basis of the divinatory evaluation process is completely obsolete. So it is troubling, even scandalous, to us that such a thoroughly nonsensical procedure (by current standards) should have afforded such lasting success. The following reflections will be devoted to this contradiction. I outline my thoughts in five points:

1. First of all I must state that the success of any prognostic procedure is little affected by the question of whether it could actually provide a glimpse into the future, as long as (1) most people believed that the applied prognostic procedure worked and (2) it did not, at least ultimately or often, interfere with sensible decision making. ${ }^{4}$ From the early second millennium B.C. until the end of cuneiform culture both conditions seem to have held true.

2. Granted, the divinatory evaluation process entailed the potential disadvantage of not being able to carry out a sensible plan because the relevant signs speak

${ }^{4}$ This, by the way, is also true for any modern prognostic procedure. 
against it. But the advantages that accompanied a plan's approval by divinatory expertise should not be underestimated. As long as the procedure was accepted as plausible, a divinatory evaluation could convincingly justify political goals and actions by showing them to be in harmony with the cosmos and the will of the gods. Divine benevolence and resultant success were thus made concretely attainable. Once consensus and a widespread sense of "Gott mit uns" (God with us) had been achieved, this led on all important levels to optimism and self-assurance, strength of purpose and readiness for action, which in turn formed a sustainable basis for a stouthearted engagement with problems when they did occur.

3. If the signs delivered a negative verdict, then it was necessary to reconsider the plan in question. This required the political decision-making committee to reopen a discussion of pros and cons. It was not unlikely that issues on which previously no consensus could be reached were once more subject to debate, to then become the object of a renewed oracular inquiry. The inquiries that have been preserved for us in connection with extispicy are true works of art, which enumerate a plan with a detailed list of the individual steps (Lambert, 2007). If a plan was decided against, it did not have to be abandoned entirely, but could be resubmitted for examination in a slightly modified form. If the proposal was then positively evaluated, it meant that the detail that had been revised in the second inquiry was responsible for the original rejection. As a consequence, it was primarily those segments of a plan causing controversy in the original draft that were reexamined.

Divinatory evaluation then, which looks to an authority higher than any human being, opens up space for substantive discussions that are relatively free of the constraints of hierarchy. Surprisingly, at first glance, divination actually promotes compromise between competing interests. The cherished Western myth of the origin of democracy in the Greek polis impedes the insight that a culture of negotiation is not necessarily bound to the agora or to the institutions with which we are familiar.

4. The theistic worldview of Mesopotamia understood divinatory evaluation as a deed-consequence relationship, in which a plan's approval or rejection was interpreted as evidence of a reward or punishment from the gods. Those in positions of leadership had to justify themselves both in the eyes of the people and of the gods. For this reason it was important for leaders to comply with demands for social justice from the religious sphere. If divination revealed the presence of a threat, and hence underlying divine wrath, then those closest to the king had to address the possibility that he had alienated the gods through ritual, personal, or some other kind of misconduct. Numerous texts show us that it was not uncommon for the king himself to be personally confronted with this verdict. Although detailed sources for this are-for obvious reasons-mostly lacking, this shows that the discussion of an unfavorable prediction created space in which a small circle of people could question the legitimacy of a king's action or plan.

5. Astrology, which continually generates unsolicited signs, requires that predictions continually be harmonized with the present situation, and that the present be measured against that which has been predicted. By requiring continual reflection 
on political actions, astrology thus produces an atmosphere of political vigilance. The astrological predictions commissioned by the Neo-Assyrian palace concerned the internal and external security of the land, the state of provisions and the outlook for the harvest (see e.g., van Soldt, 1995 passim). It was inevitable that omens concerning national security could not be discussed or even thought about without being connected to the current situation, for the future would surely unfold from the present. Forecasts of failure and defeat thus forced the review of internal and external security, of military and security force readiness, of advisor and allies trustworthiness, of the country's provision stockpiles, and many other areas. In this way, the continual astrological analysis of the expected really was, as the texts say, "the king's watch" (e.g., Parpola, 1993 , p. 111, text no. 143). By identifying negative trends even before they were noticeable or of any consequence, it fulfilled the function of a political and social early warning system.

On second thought we must concede that it would be simply unwise to dismiss ancient Near Eastern divination as mere superstition or aberration. In its day, by giving shape to the future, creating space for negotiation, and helping to build consensus, it was a decisive means of reaching political goals.

\section{References}

Brown, D. (2000). Mesopotamian planetary astronomy astrology (Cuneiform monographs, Vol. 18). Groningen, The Netherlands: STYX Publications.

Collins, D. (2008). Mapping the entrails: The practice of Greek hepatoscopy. American Journal of Philology, 129, 319-345. doi:10.1353/ajp.0.0016.

Durand, J.-M. (1988). Archives épistolaires de Mari, I/1 [Epistolary archives of Mari, I/1]. In J.-M. Durand (Ed.), Archives royales de Mari: Vol. 26/1. Paris: Édition Recherche sur les Civilisations.

Freedman, S. M. (1998). If a city is set on a height: The Akkadian omen series Šumma Alu ina Mèlê Šakin (Vol. 1, Tablets 1-21) (Occasional publications of the Samuel Noah Kramer Fund: Vol. 17). Philadelphia: Samuel Noah Kramer Fund.

Heeßel, N. P. (2008). Astrological medicine in Babylonia. In A. Akasoy, C. Burnett, \& R. YoeliTlalim (Eds.), Astro-medicine: Astrology and medicine, East and West (pp. 1-16). Florence, Italy: SISMEL, Editione del Galluzzo.

Hunger, H. (Ed.). (1992). Astrological reports to Assyrian kings (State archives of Assyria, Vol. 18). Helsinki, Finland: Helsinki University Press.

Hunger, H., \& Pingree, D. (1999). HdO: Astral sciences in Mesopotamia.Handbuch der Orientalistik, Abteilung 1, 44. Leiden, The Netherlands: Brill.

Hunger, H., \& Sachs, A. (1988-2006). Astronomical diaries and related texts from Babylonia, Vol. I: Diaries from 652 B.C. to 262 B.C. [1988]; Vol. II: Diaries from 261 B.C. to 165 B.C. [1989]; Vol. III: Diaries from 164 B.C. to 61 B.C. [1996]; Vol. V: Lunar and planetary texts [2001]; Vol. VI: Goal yeartexts [2006]. Vienna, Austria: Verlag derÖsterreichischen Akademie der Wissenschaften. Jeyes, U. (1993). Divination as a science in ancient Mesopotamia. Jaarbericht van het VooraziatischEgyptisch Genootschap Ex Oriente Lux, 32, 23-41.

Koch-Westenholz, U. (2005). Secrets of extispicy: The chapter Multäbiltu of the Babylonian extispicy series and Nisirti bārûti texts mainly from Aššurbanipal's library (Alter Orient und Altes Testament, Vol. 326). Münster, Germany: Ugarit-Verlag. 
Koch-Westenholz, U. (1995). Mesopotamian astrology: An introduction to Babylonian and Assyrian celestial divination (CNI publications, Vol. 19). Copenhagen, Denmark: Museum Tusculanum Press.

Koch-Westenholz, U. (2000). Babylonian liver omens: The chapters Manzāzu, Padānu and Pān tākalti of the Babylonian extispicy series mainly from Aršsurbanipal's library (CNI Publications, Vol. 25). Copenhagen, Denmark: Museum Tusculanum Press.

Lambert, W. G. (1957-1958). Three unpublished fragments of the Tukulti-Ninurta epic. Archiv für Orientforschung, 18, 38-51.

Lambert, W. G. (2007). Babylonian oracle questions. Winona Lake, IN: Eisenbrauns.

Leiderer, R. (1990). Anatomie der Schafsleber im babylonischen Leberorakel: Eine makroskopischanalytische Studie [Anatomy of the sheep liver in the liver oracle of Babylonia: A macroscopic analytic study]. Munich, Germany: Zuckschwerdt.

Maul, S. M. (1994). Zukunftsbewältigung: Eine Untersuchung altorientalischen Denkens anhand der babylonisch-assyrischen Löserituale (Namburbi) [Coping with the future: A study of ancient oriental thinking on the basis of Babylonian-Assyrian solving rituals (Namburbi)] (Baghdader Forschungen: Vol. 18). Mainz, Germany: Philipp von Zabern.

Maul, S. M. (2003). Omina und Orakel. A. Mesopotamien [Omina and oracle. A. Mesopotamia]. In D. O. Edzard \& M. P. Streck (Eds.), Reallexikon der Assyriologie und Vorderasiatischen Archäologie, (Vol. 10, pp. 45-88). Berlin, Germany: De Gruyter.

Maul, S. M. (2013). Die Wahrsagekunst im Alten Orient. Zeichen des Himmels und der Erde, München: Beck.

Meyer, J.-W. (1987). Untersuchungen zu den Tonlebermodellen aus dem Alten Orient [Studies of the clay liver models from the Old Orient] (Alter Orient und Altes Testament: Vol. 39). Kevelaer, Germany: Butzon \& Bercker.

Moren, S. M. (1978). The omen series "Shumma alu": A preliminary investigation (Doctoral dissertation). Philadelphia: University of Pennsylvania.

Neugebauer, O. (1975). A history of ancient mathematical astronomy. Berlin, Germany: Springer.

Nougayrol, J. (1941). Textes hépatoscopiques d'époque ancienne conservés au musée du Louvre [Hepatoscopic texts from ancient times in the Musée du Louvre]. Revue d'assyriologie et d'archéologie orientale, 38, 67-88.

Nougayrol, J. (1968). Le foie "d'orientation" BM 50494 [The liver "guide” BM 50494]. Revue d'assyriologie et d'archéologie orientale, 62, 31-50.

Oppenheim, A. L. (1996). Ancient Mesopotamia: Portrait of a dead civilization (Revised ed. completed by Erica Reiner). Chicago: University of Chicago Press.

Oppenheim, A. L. (1969). Divination and celestial observation in the last Assyrian empire. Centaurus, 14, 97-135.

Parpola, S. (1983). Assyrian library records. Journal of Near Eastern Studies, 42, 1-29.

Parpola, S. (Ed.). (1993). Letters from Babylonian and Assyrian scholars (State archives of Assyria, Vol. 10). Helsinki, Finland: Helsinki University Press.

Pfiffig, A. J. (1975). Religio etrusca [The Etruscan religion]. Graz, Austria: Akademische Druckund Verlagsanstalt.

Pongratz-Leisten, B. (1999). Herrschaftswissen in Mesopotamien: Formen der Kommunikation zwischen Gott und König im 2. und 1. Jahrtausend v. Chr. [The knowledge of rule in Mesopotamia: Forms of communication between god and king in the 2nd and 1st millennia B.C.] (State Archives of Assyria Studies: Vol. 10). Helsinki, Finland: Neo-Assyrian Text Corpus Project.

Reiner, E. (1995). Astral magic in Babylonia. Transactions of the American Philosophical Society, $85(4), 1-150$.

Rochberg-Halton, F. (2004). The heavenly writing: Divination, horoscopy, and astronomy in Mesopotamian culture. Cambridge, UK: Cambridge University Press.

Sasson, J. M. (Ed.). (1995). Civilizations of the ancient Near East. New York: Scribner.

Starr, I. (1990). Queries to the Sungod: Divination and politics in Sargonid Assyria (State archives of Assyria, Vol. 4). Helsinki, Finland: Helsinki University Press. 
Starr, I. (1983). The rituals of the diviner (Bibliotheca mesopotamica, Vol. 12). Malibu, CA: Undena Publications.

Thulin, C. O. (1968). Die etruskische Disziplin [The Etruscan discipline]. Darmstadt, Germany: Wissenschaftliche Buchgesellschaft.

van Soldt, W. H. (1995). Solar omens of Enuma Anu Enlil: Tablets 23 (24)-29 (30) (Uitgaven van het Nederlands Historisch-Archeologisch Instituut te Istanbul, Vol. 73). Istanbul, Turkey: Nederlands Historisch-Archaeologisch Instituut.

von Weiher, E. (1993). Uruk, Spätbabylonische Texte aus dem Planquadrat U 18, 4: Ausgrabungen in Uruk Warka. Endberichte herausgegeben von Rainer Michael Boehmer, 12. [Uruk, late Babylonian texts from plan grid square U 18, Part 4: Excavations in Uruk Warka (Final reports, R. M. Boehmer, Ed.)], Vol. 12. Mainz, Germany: Philipp von Zabern. 